\title{
Erratum zu: Wege durch die Unternehmenskrise
}

\section{Erratum zu: \\ C. Niering und C. Hillebrand, Wege durch die Unternehmenskrise, https://doi.org/10.1007/978-3-658-23145-3}

Trotz sorgfältiger Erstellung unserer Bücher lassen sich Fehler nicht vermeiden, daher weisen wir auf Folgendes hin:

In der vorliegenden Version wurden Rechtschreibfehler sowie die Nummerierung der Verweise auf Muster im Anhang korrigiert.

Die aktualisierte Version des Buches finden Sie unter https://doi.org/10.1007/978-3-658-23145-3 